\title{
Nutritivna vrijednost krumpira i njegov utjecaj na ljudsko zdravlje
}

\begin{abstract}
Sažetak
Budućida svjetska populacija raste, FAO (Organizacija za hranu ipoljoprivredu Ujedinjenih naroda) smatra krumpir važnom namirnicom koja bi mogla imati glavnu ulogu kao osnovna hrana sadašnjih i buducíh generacija. Krumpir ima veliku važnost u prehrani ljudi iz više razloga: jednostavan način uzgoja, visoki prinosi i potrošnja, prihvatljiva cijena, jednostavni i različiti načini pripreme. Kako se krumpir konzumira u većim količinama, male razlike u nutritivnim sastojcima krumpira imaju velik utjecaj na zdravlje stanovništva.

Krumpir je hrana bogata ugljikohidratima (škrobom), dok je udio proteina u krumpiru vrlo nizak, no ima izvrsnu biološku vrijednost od 90 do 100 (u odnosu na referentnu vrijednost proteina jaja koja je 100). Krumpir sadrži vitamin C te neke od vitamina B skupine. Nadalje, jedan je od najpristupačnijih izvora minerala kalija $i$ to $u$ količini koja je značajno veća u usporedbi s namirnicama koje su identificirane kao glavni izvori kalija, poput brokule, banane i naranče. Krumpir sadrži i razne fitonutrijente koji imaju antioksidacijsko djelovanje. Među te važne spojeve koji djeluju na smanjenje slobodnih radikala i time doprinose zdravlju pripadaju fenolne kiseline poput klorogenske i kafeinske, flavonoidi, karotenoidi te mnogi drugi. Kora krumpira sadrži značajnu količinu dijetetskih vlakana. Osim hranjivih sastojaka, gomolji krumpira sadrže i neke nepoželjne tvari, antinutrijente, poput glikoalkaloida solanina i hakonina, ali u zdravim konzumnim krumpirima se nalaze u količinama daleko ispod maksimalno dozvoljenih vrijednosti. Stoga, ovaj rad sažima podatke samo o nutritivnim svojstvima krumpira i njihovom utjecaju na zdravlje ljudi.
\end{abstract}

Ključne riječi: krumpir, nutritivni sastojci, prerada, fitokemikalije, zdravlje

\section{Uvod}

Uz pšenicu, kukuruz i rižu, po zasađenim površinama krumpir (Solanum tuberosum L.) je četvrta kultura na svijetu, a široko je rasprostranjen i u Republici Hrvatskoj. Prema Državnom zavodu za statistiku RH ukupna proizvodnja krumpira u RH u 2018. godini iznosila je $152000 \mathrm{t}$ na 7000 ha površine, a u 2017. god. 126000 t (kasnog i sjemenskog) na 8000 ha, čime je krumpir povrće s najvećom godišnjom proizvodnjom.

Kemijski sastav i odnos hranjivih tvari razlikuju se ovisno o sorti krumpira, ali i o cijelom nizu ekoloških i proizvodnih faktora (zemljište, gnojidba, klimatski uvjeti, itd.) te načinu pripreme. Prosječne vrijednosti udjela vode, ugljikohidrata, vlakana, proteina, šećera i masti prikazane su na slici 1, a vitamina i minerala u tablici 1. 


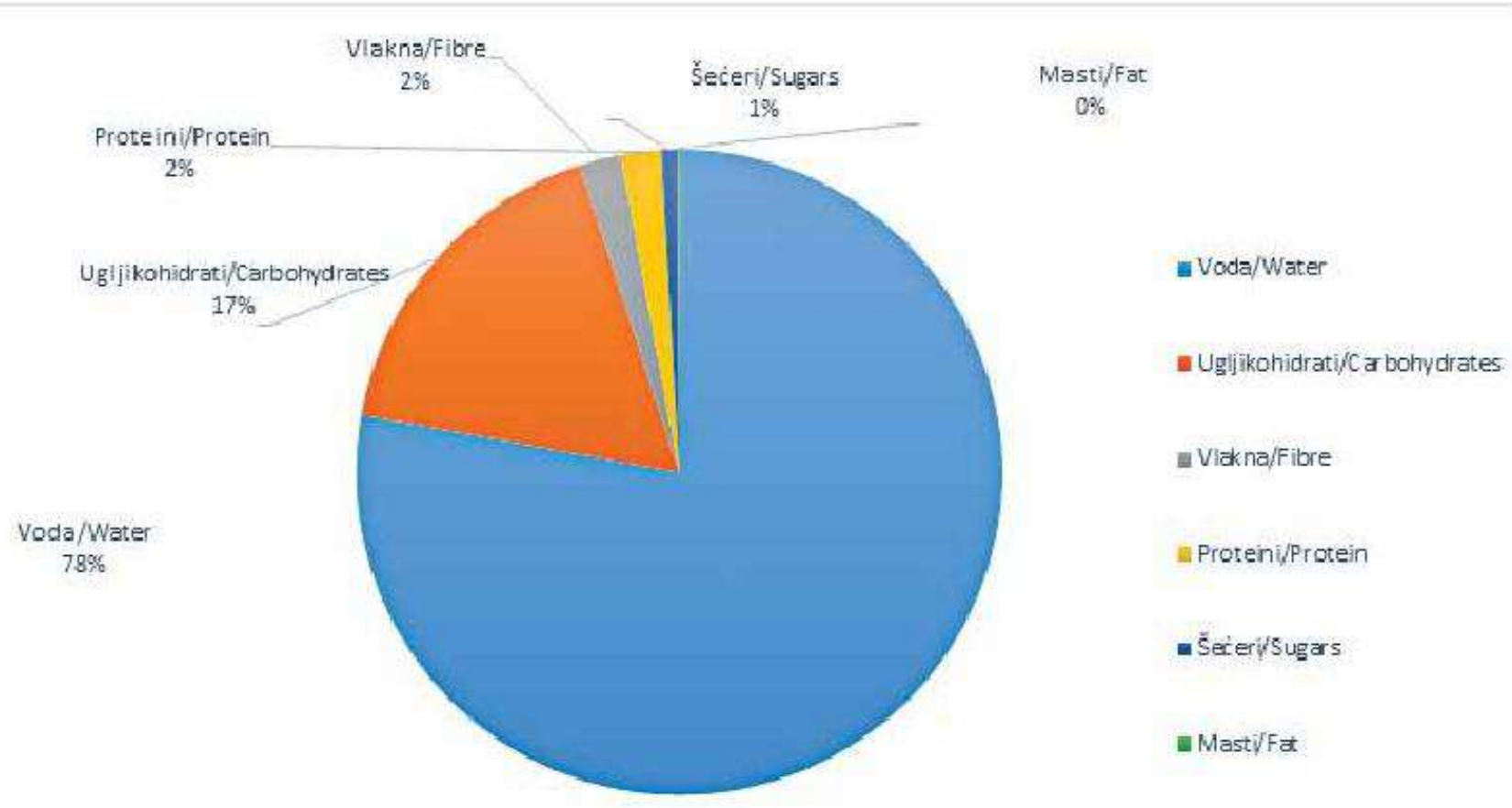

Slika 1. Udio nutritivnih sastojaka (\%) u krumpiru na $100 \mathrm{~g} /$

Figure 1. Nutrient content (\%) of potatoes per $100 \mathrm{~g}$

Izvor/Source: USDA 04/01/2019 United States Department of Agriculture Release 16, NDB Number 11352

Tablica 1. Udio vitamina i minerala (mg, $\mu \mathrm{g})$ u svježem krumpiru na $100 \mathrm{~g} /$

Table 1. Vitamin and mineral content $(\mathrm{mg}, \mu \mathrm{g})$ of fresh potatoes per $100 \mathrm{~g}$

$\begin{array}{llr} & \text { Količina/ } & \text { Količina/ } \\ \text { Naziv/Name } & \text { Amount } & \text { Naziv/Name }\end{array}$

\begin{tabular}{lccc}
\hline Vitamin C/Vitamin C (mg) & 19,7 & Željezo/Iron $(\mathrm{mg})$ & 0,81 \\
\hline Tiamin/Thiamin (mg) & 0,081 & Magnezij/Magnesium $(\mathrm{mg})$ & 23 \\
\hline Riboflavin/Riboflavin $(\mathrm{mg})$ & 0,032 & Fosfor/Phosphorus $(\mathrm{mg})$ & 57 \\
\hline Niacin/Niacin $(\mathrm{mg})$ & 1,061 & Kalij/Potassium $(\mathrm{mg})$ & 425 \\
\hline $\begin{array}{l}\text { Pantotenska kiselina/ } \\
\text { Pantothenic acid }(\mathrm{mg})\end{array}$ & 0,295 & Natrij/Sodium $(\mathrm{mg})$ & 6 \\
\hline $\begin{array}{l}\text { Vitamin B6/Vitamin B6 } \\
(\mathrm{mg})\end{array}$ & 0,298 & Cink/Zinc $(\mathrm{mg})$ & 0,3 \\
\hline Folati/Folate $(\mu \mathrm{g})$ & 15 & Bakar/Copper $(\mathrm{mg})$ & 0,11 \\
\hline Vitamin E $(\mathrm{mg})$ & 0,01 & Mangan/Manganese $(\mathrm{mg})$ & 0,153 \\
\hline Vitamin K $(\mu \mathrm{g})$ & 2 & Selen/Selenium $(\mu \mathrm{g})$ & 0,4 \\
\hline
\end{tabular}

Izvor/Source: USDA 04/01/2019 United States Department of Agriculture Release 16, NDB Number 11352 
Nutritivna vrijednost prerađenog krumpira uvelike ovisi o načinu pripreme ove namirnice. Kuhanje i pečenje u pećnici imaju prednost u odnosu na popularne pržene „krumpiriće” koje bi trebalo izbjegavati. Osim toga, kod kuhanja ili pečenja krumpira, poželjno je da ga se priprema zajedno s korom, bez guljenja, jer će se tako sačuvati značajne količine vitamina i minerala (tablica 2).

Tablica 2. Nutritivne vrijednosti različito pripremljenog krumpira na $100 \mathrm{~g} /$

Table 2. Typical nutrient values of different potato preparations per $100 \mathrm{~g}$

\begin{tabular}{|c|c|c|c|c|c|}
\hline & $\begin{array}{l}\text { Kuhani krumpir, } \\
\text { u kori/ Boiled } \\
\text { potatoes, in } \\
\text { skins }\end{array}$ & $\begin{array}{l}\text { Kuhani } \\
\text { krumpir, } \\
\text { oguljen/ } \\
\text { Boiled } \\
\text { potatoes, } \\
\text { peeled }\end{array}$ & $\begin{array}{l}\text { Pečeni krumpir, } \\
\text { u kori/ Baked } \\
\text { potatoes, in skin }\end{array}$ & $\begin{array}{l}\text { Pireod } \\
\text { krumpira*/ } \\
\text { Mashed } \\
\text { potatoes }\end{array}$ & $\begin{array}{l}\text { Pomfrit, } \\
\text { maloprodaja } \\
\text { /French fries, } \\
\text { retail }\end{array}$ \\
\hline Energija/Energy (kcal) & 66 & 77 & 85 & 104 & 280 \\
\hline Proteini/Protein (g) & 1,4 & 1,8 & 2,6 & 1,8 & 3,3 \\
\hline $\begin{array}{l}\text { Ugljikohidrati/ } \\
\text { Carbohydrates (g) }\end{array}$ & 15,4 & 17,0 & 17,9 & 15,5 & 34,0 \\
\hline Masti /Fat (g) & 0,3 & 0,1 & 0,1 & 4,3 & 15,5 \\
\hline Vlakna/Fibre (g) & 1,5 & 1,2 & 3,1 & 1,1 & 2,1 \\
\hline Kalij/Potassium (mg) & 460 & 280 & 547 & 260 & 650 \\
\hline Željezo/Iron (mg) & 1,6 & 0,4 & 0,9 & 0,4 & 1,0 \\
\hline Vitamin $B_{1}(\mathrm{mg})$ & 0,13 & 0,18 & 0,11 & 0,16 & 0,08 \\
\hline Vitamin $B_{6}(\mathrm{mg})$ & 0,33 & 0,33 & 0,23 & 0,30 & 0,36 \\
\hline Folati/Folate $(\mu \mathrm{g})$ & 19 & 19 & 44 & 24 & 31 \\
\hline Vitamin C (mg) & 9 & 6 & 14 & 8 & 4 \\
\hline
\end{tabular}

* s mlijekom (7 g) i maslacem (5 g)/ with milk (7 g) and butter (5 g)

Izvor/Source: McCance and Widdowsons's The Composition of Foods, (2002) 6th summary edition. Food Standards Agency. Cambridge: Royal Society of Chemistry.

Food Composition and Nutrition Tables, 7th revised and completed edition, Ed. SW Souci, W Fachmann, H Kraut. Wissenschaftliche Verlagsgesellschaft mbH, Stuttgart, 2008.

Osim što je dobar izvor nutritivno vrijednih sastojaka, kemijski sastav krumpira sadrži i bioaktivne molekule kojima se pripisuju potencijalno pozitivni utjecaji na zdravlje kao što su antioksidacijski, hepatoprotektivni, protuupalni, antitumorski, antidijabetički, antimikrobni i „antiaging" učinci. Nadalje, krumpir ne sadrži gluten te je neizostavan sastojak bezglutenske prehrane za osobe koje imaju intoleranciju na gluten koji je pak prisutan u pšenici, raži, njihovim brojnim proizvodima i još mnogim drugim namirnicama (Shepherd i sur., 2013).

\section{Makronutrijenti}

Škrob

Škrob je složeni ugljikohidrat te je najzastupljeniji ugljikohidrat u krumpiru, pa se stoga krumpir zbog veće količine škroba klasificira i kao „škrobno povrće“. Ugljikohidrati čine oko 75 $\%$ ukupne suhe tvari krumpira. Škrob čini oko $18 \%$ mase svježeg krumpira i nalazi se u granulama sastavljenim od amiloze - ravnolančani glukozni polimer (rezistentni) i amilopektina 
- razgranati glukozni polimer (probavljivi) (Jansen i sur., 2001). Omjer amiloze i amilopektina te fosforilacija molekule škroba utječu na njegovu probavljivost (Camire i sur., 2009). Amiloza čini oko 31 \% ukupnog škroba u krumpiru (Jansen i sur., 2001). Nakon kuhanja, škrob s više amiloze ima tendenciju kristalizacije tijekom hlađenja, čineći ga otpornim na probavne enzime (Camire i sur., 2009) tako da je kuhani pa ohlađeni krumpir $\left(4^{\circ} \mathrm{C}\right)$ dobar izvor rezistentnog škroba. Rezistentni škrob se ne probavlja u tankom crijevu, ali prolazi do debelog crijeva gdje dolazi do fermentacije, te proizvodnje poželjnih kratko-lančanih masnih kiselina kao i povećane sinteze raznih „dobrih“ bakterija tzv. probiotika (Sun i sur., 2016). Time rezistentni škrob ima blagotvorne zdravstvene učinke na debelo crijevo (Higgins i Brown, 2013; Murphy i sur., 2008). Ekstrakt krumpira koji sadrži $70 \%$ rezistentnog škroba smanjuje količinu proteobakterija kao što su Escherichia coli i Shigella, a povećava količinu poželjnih bifidobakterija u crijevima starijih ljudi (Alfa i sur., 2018). Ukupni pozitivan učinak rezistentnog škroba je poboljšanje tolerancije na glukozu i osjetljivost na inzulin, smanjenje razine lipida u krvi, te povećanje osjećaja sitosti tako da se može koristiti u prehrani za regulaciju tjelesne mase (Bodinham i sur., 2010). Za usporedbu, količina rezistentnog škroba na $100 \mathrm{~g}$ u sljedećim namirnicama je: pšenica $6,2 \mathrm{~g}$, bijeli grah $4,2 \mathrm{~g}$, banana $4 \mathrm{~g}$, čips od krumpira $3,5 \mathrm{~g}$, leća $3,4 \mathrm{~g}$, krumpir kuhani i ohlađeni $3,2 \mathrm{~g}$, krumpir pržen $2,8 \mathrm{~g}$, slanutak $2,6 \mathrm{~g}$, grašak $1,9 \mathrm{~g}$ (Murphy i sur., 2008).

\section{Dijetetska ili prehrambena vlakna}

Dijetetska vlakna krumpira se nalaze uglavnom u peridermi (kori), koji čini oko 1-2 \% gomolja, a u kori na vlakna otpada 50 \% (Lazarov i Werman, 1996). Jedan srednji krumpir s korom okvirno sadrži oko $2 \mathrm{~g}$ dijetetskih vlakana. Tako da krumpir, općenito ne samo zbog rezistentnog škroba, doprinosi unosu dijetetskih vlakana (Slavin, 2008) koje karakterizira otpornost na djelovanje enzima probavnog sustava te podložnost nekih vrsta vlakana fermentaciji u debelom crijevu pomoću prisutnih bakterija. Shodno tome, imaju slične zdravstvene koristi uključujući poboljšanje razine lipida u krvi, regulaciju glukoze u krvi i povećanje sitosti, što može pomoći u prehranama koje se primjenjuju za smanjenje tjelesne mase (Lattimer i Haub, 2010). Dijetetska krumpirova vlakna povećavaju broj bifidobakterija i/ili laktobacila (Paturi i sur., 2012), a pokazalo se da vežu i žučne kiseline što se smatra da je jedan od mehanizama kojim utječu na smanjenje kolesterola u plazmi (Lazarov i Werman, 1996).

\section{Šećeri}

Od jednostavnih šećera krumpir sadrži glukozu, fruktozu i saharozu (Zhu i sur., 2010). Njihov udio varira značajno između i unutar sorti, unutar gomolja i tijekom razvoja gomolja (Navarre i sur., 2013; Watada i Kunkel, 1955). Amrein i sur. (2003) izvijestili su o udjelu slobodnog šećera u 17 sorti s rasponom 30-1537 mg fruktoze, 97-2550 mg glukoze i 430-1597 mg saharoze na 1 kg mase svježeg krumpira. Skladištenje može utjecati na omjer škroba i šećera u krumpiru, gdje pri nižim temperaturama može doći do povećanja glukoze u krumpiru uslijed enzimske hidrolize škroba u glukozu (Watada i Kunkel, 1955). Ovaj postupak ima štetan utjecaj na kvalitetu prženog krumpira zbog mogućeg nastanka nepoželjnog akrilamida u reakciji s asparaginom pri povišenoj temperaturi (Zhu i sur., 2010). Prženjem krumpira u dubokoj masnoći i zagrijavanjem na temperaturu iznad $120^{\circ} \mathrm{C}$ nastaje akrilamid (Tareke i sur., 2002), koji je potencijalno kancerogen (Mestdagh i sur., 2007). Aminokiselina asparagin i reducirajući šećeri (glukoza i fruktoza) identificirani su kao glavni prekursori nastanka akrilamida (Becalski i sur., 2003). Amrein i sur. (2003) navode da se udio akrilamida u proizvodima od krumpira može značajno smanjiti prvenstveno odabirom kultivara s niskim koncentracijama reducirajućih šećera, odnosno prema Biedermannu-Bremu i sur. (2003) trebaju imati reducirajuće šećere manje od $1 \mathrm{~g} / \mathrm{kg}$ svježeg krumpira. 


\section{Proteini}

Krumpir sadrži između 2 i $2,5 \%$ proteina, a od toga $40 \%$ čine proteini topljivi u vodi (Shewry, 2003). Interesantan protein krumpira je patatin obzirom na njegovu enzimsku (lipaznu) aktivnost (Spelbrink i sur., 2015). Općenito, udio proteina ovisi o sorti krumpira i zrelosti, ali sadrži svih devet esencijalnih aminokiselina te je dobre nutritivne kvalitete (Woolfe, 1987). Stoga, krumpir ima relativno visoku "biološku vrijednost" koja iznosi 90 (referentna vrijednost je 100 koju ima protein jaja), dok npr. soja ima 84 i grah 73 . Nedavno istraživanje o udjelu proteina i aminokiselina u komercijalno dostupnim biljnim izolatima proteina otkrilo je da je protein krumpira bolji od ostalih biljnih izvora te je sličan životinjskim proteinima u pogledu udjela esencijalnih aminokiselina posebno po udjelu leucina, izoleucina i lizina (Gorissen i sur., 2018). Prisutne aminokiseline u krumpiru prvenstveno su asparagin, glutaminska i asparaginska kiselina, dok metionina, cisteina i histidina ima manje, pri čemu je asparagin, kao najzastupljenija aminokiselina u krumpiru, povezana sa stvaranjem već spomenutog nepoželjnog akrilamida (Zhu i sur., 2010).

\section{Lipidi}

Lipidi su u krumpiru prisutni u vrlo malom postotku tako da na $150 \mathrm{~g}$ svježeg krumpira lipida ima oko 0,15 g. Ova količina je puno manja nego u riži $(1,95 \mathrm{~g})$ i tjestenini $(0,5 \mathrm{~g})$ (Priestley, 2006). Od masnih kiselina u krumpiru dominantne su palmitinska, linolna i linolenska kiselina koje su ukupno zastupljene u udjelu od čak $90 \%$. Kombinirani polinezasićeni lipidi čine oko 70-76 \% lipida krumpira i uglavnom su povezani s membranskim lipoproteinskim strukturama (Galliard, 1973).

\section{Mikronutrijenti \\ Vitamin C}

Krumpir sadrži značajnu količinu vitamina $C$ što može pridonijeti ukupnoj dnevnoj potrebi za vitaminom C. lako krumpir ima znatno manje vitamina $C$ u odnosu na agrume i paprike te se djelomično razgrađuje tijekom pripreme, njegovo konzumiranje ipak može doprinijeti zadovoljavanju dnevnih potreba za ovim vitaminom. Podaci govore da je krumpir kao izvor vitamina C u prehrani Amerikanaca čak na petom mjestu (Cotton i sur., 2004). Vitamin C topljiv je u vodi i djeluje kao antioksidans, stabilizirajući ili eliminirajući slobodne radikale te pomaže u sprečavanju oštećenja stanica. On također pomaže u stvaranju kolagena, potrebnog za održavanje zdravih desni, a važan je i u zacjeljivanju rana te u apsorpciji željeza iz biljne hrane i općenito povoljno djeluje na imunitet (Gropper i Smith, 2013).

\section{Vitamin B6}

U krumpiru je prisutno nekoliko vitamina B skupine: folna kiselina, niacin, piridoksin (B6), riboflavin i tiamin. Srednja porcija kuhanog krumpira (180 g) sadrži više od jedne šestine dnevnih potreba odraslih za vitaminima B1, B6 i folatima. Krumpir je dobar izvor vitamina B6 koji je topljiv u vodi i ima važnu ulogu u metabolizmu ugljikohidrata i proteina, a potreban je i za sintezu aminokiselina te hemoglobina (Finglas, 2010). Nadalje, vitamin B6 važan je za ispravno funkcioniranje živčanog sustava te za stvaranje amina, odnosno neurotransmitera koji prijenose impulse preko živčanih stanica npr. serotonina, čiji je nedostatak povezan s depresijom; melatonina, potrebnog za dobar san; epinefrina i norepinefrina, koji pomažu u reakciji na stres; i gama-aminomaslačne kiseline (GABA) potrebne za normalno funkcioniranje mozga. Vitamin B6 sudjeluje i u tzv. procesima metilacije, kemijskim procesima koji imaju značajnu ulogu u prevenciji raka, jer se uslijed metilacije toksičnih tvari potiče njihova eliminacija iz tijela. Metilacija je također važna za kardiovaskularni sustav, jer se metilacijom homocisteina zaustav- 
ljaju njegovi negativni učinci poput oštećenja stijenki krvnih žila. Vitamin B6 potreban je i za razgradnju glikogena, polisaharida glukoze koji predstavlja zalihu glukoze u mišićima i jetri (Leklem, 1987).

\section{Minerali krumpira}

Mineralne soli i minerali u tragovima igraju važnu ulogu u ljudskom organizmu te se moraju neprestano nadopunjavati prehranom. Krumpir sadrži najviše kalija, dok ne sadrži natrij. Također, svježi krumpir sadrži kalcij $(6-18 \mathrm{mg} / 100 \mathrm{~g})$ i fosfor $(30-60 \mathrm{mg} / 100 \mathrm{~g})$. Važni minerali krumpira su i magnezij ( 25 mg/100 g svježeg krumpira) te cink i željezo. Krumpir je važan izvor minerala u prehrani s obzirom na njegov dnevni unos, jer omogućuje 30-48 \% preporučenog dnevnog unosa (\% RDI) za makrominerale (osim kalcija i natrija) i 6-82 \% preporučenog dnevnog unosa minerala u tragovima. Minerali krumpira nalaze se uglavnom u kori te se preporučuje konzumacija krumpira s korom. Kalij je najzastupljeniji mineral u krumpiru i nalazi se u rasponu od 400 do $560 \mathrm{mg}$ na $100 \mathrm{~g}$ mase svježeg gomolja što je znatno više nego u namirnica koje se općenito smatraju bogate kalijem poput brokule $(460 \mathrm{mg})$, banane $(450 \mathrm{mg})$, naranče (250 mg) te gljiva (300 mg) (Drewnowski i sur., 2013). Značajno utječe na distribuciju vode u tijelu regulirajući osmotski tlak u stanici. Istraživanja navode da dijeta bogata kalijem i siromašna natrijem smanjuje rizik od hipertenzije i moždanog udara (Seth i sur., 2014). U znanstvenoj izjavi kojom se promoviraju prehrambeni pristupi prevenciji i liječenju hipertenzije, Američka udruga za srce (AHA) izvijestila je da dokazi iz pokusa na životinjama, opservacijskih studija i više od 30 kliničkih ispitivanja na ljudima pokazuju značajnu povezanost između visokog unosa kalija i smanjenog krvnog tlaka. Appel i sur. (2006) također navode obrnutu vezu između unosa kalija i krvnog tlaka kod osoba s povišenim krvnim tlakom i onih koji to nisu. Još jedna nedavna studija ispitala je povezanost između unosa kalija i moždanog udara u skupini od 90.137 žena u menopauzi i otkrila je da je visok unos kalija povezan s manjim rizikom od moždanog i ishemijskog moždanog udara (Seth i sur., 2014).

Andre i sur. (2007) navode udio željeza od 30 do $155 \mu \mathrm{g} / \mathrm{g}$ svježeg krumpira, kalcija 272-

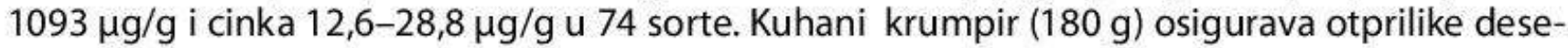
tinu dnevne potrebe magnezija i željeza za odraslu osobu (Volpe, 2013). lako udio željeza u krumpiru nije osobito visok, njegova bioraspoloživost veća je od mnogih drugih vrsta povrća bogatih željezom, jer je u krumpiru prisutna izuzetno niska razina kelata i drugih spojeva (npr. tanina) koji inhibiraju apsorpciju željeza i vitamina C (Brown, 2008). Magnezij je četvrti najzastupljeniji mineral koji se nalazi u tijelu i služi kao koenzim za preko 300 metaboličkih reakcija važnih za funkcije poput sinteze proteina, proizvodnje energije, prijenosa živčanih impulsa, regulacije krvnog tlaka i kontrakcije mišića (Gröber i sur., 2015). Niske razine magnezija povezane su s nizom kroničnih bolesti, uključujući migrensku glavobolju, Alzheimerovu bolest, moždani udar, hipertenziju, kardiovaskularne bolesti i dijabetes melitus tipa 2 (Volpe, 2013). Bioraspoloživost cinka, također, veća je u krumpiru nego u mnogim drugim vrstama voća i povrća. Cink je ključni element za pravilno funkcioniranje kognitivnih vještina mozga (Bhatnagar i Taneja, 2001).

\section{Fitokemikalije (fitonutrijenti)}

Fitokemikalije su spojevi s antioksidacijskom aktivnošću koji se nalaze u biljnoj hrani i pripadaju tzv. biološki aktivnim spojevima. To su sekundarni proizvodi biljnog metabolizma koji služe biljci u obrani te imaju važnu ulogu i u očuvanju ljudskog zdravlja. Općenito to su biljni pigmenti poput fenolnih spojeva, karotenoida i drugih.

Krumpir sadrži fenolne spojeve i karotenoide koji su u prehrani vrlo poželjni zbog svog povoljnog utjecaja na ljudsko zdravlje. Udio i sastav biološki aktivnih spojeva različit je ovisno 
o sortama krumpira (Al-Saikhan i sur., 1995; Brown, 2005; Brown, 2008). Na koncentraciju i stabilnost ovih sastojaka utječu i drugi čimbenici kao što su agronomski faktori, skladištenje nakon žetve, uvjeti kuhanja i prerade.

Od fenolnih spojeva u krumpiru prisutna je klorogenska kiselina koja predstavlja $90 \%$ ukupnog fenolnog sastava gomolja krumpira, a nalazi se uglavnom između korteksa i kore (Liu, 2013). U $100 \mathrm{~g}$ svježeg mesa bijelog krumpira ima do $30 \mu \mathrm{g}$ flavonoida. Iz skupine flavonoida najzastupljeniji su katehin i epikatehin. Kvercetin je flavonoid sa značajnom biološkom aktivnosti (Kawabata i sur., 2015) i među različitim sortama krumpira najviše ga ima crveni krumpir.

Karotenoidi, poput luteina i zeaksantina, nalaze se uglavnom u žutom i crvenom krumpiru, iako se male količine nalaze i u bijelom krumpiru. Udio karotenoida prema literaturi kreće se od 50 do $100 \mu \mathrm{g}$ na $100 \mathrm{~g}$ svježe mase u bijelo obojenim sortama te do $2000 \mu \mathrm{g}$ u žuto do narančasto obojenih sorti. Tamno žute sorte sadrže otprilike 10 puta više karotenoida od bijelih sorti (Brown, 2008). Boja crvenog i ljubičastog krumpira potječe od antocijana. Sama pokožica može biti pigmentirana, a meso može biti djelomično ili u potpunosti pigmentirano. Cijeli neoguljeni krumpir s potpunom pigmentacijom mesa može imati do $40 \mathrm{mg}$ ukupnih antocijana na $100 \mathrm{~g}$ svježe mase (Brown, 2005).

Mnoge kronične bolesti poput raka, kardiovaskularnih i koronarnih bolesti srca, dijabetesa i Alzheimerove bolesti povezane su s prekomjernim nastankom slobodnih radikala u našem organizmu (Willcox i sur., 2004), a navode se i kao vodeći uzrok smrti u industrijski razvijenim zemljama. lako organizam ima mogućnosti obrane od štetnog učinka slobodnih radikala ponekad je to nedovoljno pa se stoga preporučuje konzumirati hranu bogatu antioksidansima s obzirom na to da imaju značajnu ulogu u neutralizaciji slobodnih radikala i ublažavanju njihovog štetnog djelovanja.

\section{Zaključak}

Krumpir ima značajnu ulogu u sprječavanju pothranjenosti u siromašnim područjima, a njegova konzumacija doprinosi zdravlju. Nažalost, krumpir je označen kao "hrana koju treba izbjegavati" zbog nedosljednih istraživanja koja pokazuju da je "zapadnjački" način prehrane, koji je uključivao sav krumpir bez obzira na način pripreme, povezan s povećanjem kilograma i povećanim rizikom od dijabetesa tip 2. Stoga se zanemaruje uloga krumpira kao jeftinog izvora nutritivnih sastojaka, a samo po sebi konzumiranje krumpira ne pridonosi pretilosti. Krumpir doprinosi unosu važnih nutritivnih sastojaka u prehrani, uključujući kalij, vitamin C i dijetetska vlakna te sadrži fitokemikalije koje opravdavaju tvrdnju da je poželjan dio svakodnevne prehrane. Istraživanja pokazuju da hranjive tvari i komponente krumpira mogu imati povoljan utjecaj na krvni tlak, sitost i zdravlje probavnog sustava te se može zaključiti da navedeni nutritivni doprinosi čine krumpir važnom i uglavnom podcijenjenom namirnicom u prehrani mnogih populacija širom svijeta.

\section{Zahvala}

Ovaj rad je financirala Hrvatska zaklada za znanost projektom IP-2016-06-5343 „Inovativne tehnike u minimalnoj preradi krumpira (Solanum tuberosum) i njegova zdravstvena ispravnost nakon pripreme".

\section{Literatura}

Alfa, J.M., Strang, D., Tappia, P.S., Graham, M.,Van Domselaar, G., Forbes, J.D., V. Laminman, V., Olson, N., DeGagne, P., Bray, D., Murray, B.L., Dufault, B., Lix. L.M. (2018) A randomized trial to determine the impact of a digestion resistant starch composition on the gut microbiome in older and mid-age adults. Clinical Nutrition, 37 (3), $797-807$.

Al-Saikhan, M.S., Howard, L.R., Miller, J.C. (1995) Antioxidant activity and total phenolics in different genotypes of potato (Solanum tuberosum L.). Journal of Food Science, 60 (2), 341-343.

Amrein, T. M., Bachmann, S., Noti, A., Biedermann, M., Barbosa, M. F., Biedermann-Brem, S., Grob, K., Keiser, A., 
Realini, P., Escher, F., Amado, R. (2003) Potential of acrylamide formation, sugars, and free asparagine in potatoes: a comparision of cultivars and farming systems. Journal of Agricultural and Food Chemistry, 51 (18), $5556-5560$.

Andre, C. M., Ghislain, M., Bertin, P., Oufir, M., del Rosario Herrera, M., Hoffmann, L., Hausman, J-F., Larondelle, Y., Evers, D. (2007) Andean potato cultivars (Solanum tuberosum L.) as a source of antioxidant and mineral micronutrients. Journal of Agricultural and Food Chemistry, 55 (2), 366-378.

Appel, L.J., Brands, M.W., Daniels, S.R., Karanja, N., Elmer, P.J., Sacks, F.M. (2006) Dietary approaches to prevent and treat hypertension. A scientific statement from the American Heart Association, Hypertension, 47 (2), 296-308.

Becalski, A., Lau, B.P.Y., Lewis, D., Seaman, S.W. (2003) Acrylamide in foods: occurrence, sources, and 340 modeling. Journal of Agricultural and Food Chemistry, 51 (3), 802-808.

Bhatnagar, S., Taneja, S. (2001) Zinc and cognitive development. British Journal of Nutrition, 85 (2) S139-S145.

Biedermann-Brem, S., Noti, A., Grob, K., Imhof, D., Bazzocco, D., Pfefferle, A. (2003) How much reducing sugar may

potatoes contain to avoid excessive acrylamide formation during roasting and baking? European Food Research and Technology, 217 (5), 369-373.

Bodinham, C.L., Frost, G.S., Roberston, M.D., (2010) Acute ingestion of resistant starch reduces food intake in health adults. British Journal of Nutrition, 103 (2), 917-922.

Brown, C. R. (2008) Breeding for phytonutrient enhancement of potato. American Journal of Potato Research, 85,

298-307.

Brown, C. R. (2005) Antioxidants in potato. American Journal of Potato Research, 82 (2), 163-172.

Camire, M.E., Kubow, S., Donnelly, DJ. (2009) Potatoes and human health, Critical Reviews in Food Science and Nutrition, 49 (19), 823-840.

Cotton, P.A., Subar, A.F., Friday, J.E. (2004) Cook A. Dietary sources of nutrients among US adults, 1994-1996. Journal of the American Dietetic Association, 104 (6), 921-930.

Drewnowski, A., Rehm, C.D., (2013) Vegetable cost metrics show that potatoes and beans provide most nutrients per penny. PLoS One, 15 (5) 8.

Finglas, P.M. (2010) Dietary Reference Intakes for Thiamin, Riboflavin, Niacin, Vitamin B6, Folate, Vitamin B12. Trends in Food Science and Technology, 11 (8), 296-297.

McCance and Widdowsons's The Composition of Foods, (2002) 6th summary edition. Food Standards Agency. Cambridge: Royal Society of Chemistry.

Food Composition and Nutrition Tables, 7th revised and completed edition, Ed. SW Souci, W. Fachmann, $\mathrm{H}$ Kraut. Wissenschaftliche Verlagsgesellschaft $\mathrm{mbH}$, Stuttgart, 2008.

Galliard, T. (1973) Lipids of potato tubers. 1. Lipid and fatty acid composition of tubers from different varieties of potato. Journal of the Science of Food and Agriculture, 24 (5), 617-622.

Gorissen, S. H.M., Crombag, J. J.R., Senden, J. M.G., Waterval, W. H., Bierau, J., Verdijk, L. B., van Loon, L. J. (2018)

Protein content and amino acid composition of commercially available plant-based protein isolates. Amino acids, 50 (12), 1685-1695.

Gropper, S.S., Smith, J.L., (2013) Advanced Nutrition and Human Metabolism. 6th Ed. Wadsworth Publishers. Belmont, CA.

Gröber, U., Schmidt, J., Kisters, K. (2015) Magnesium in Prevention and Therapy. Nutrients, 7 (9), 8199-8226.

Higgins, J.A., Brown, I.L. (2013) Resistant starch: a promising dietary agent for the prevention/treatment of in-

flammatory bowel disease and bowel cancer. Current Opinion in Gastroenterology, 29 (2), 190-194.

Jansen, G., Flamme, W., Schuler, K., Vandrey, M. (2001) Tuber and starch quality of wild and cultivated potato spe-

cies and cultivars, Potato Research, 44 (2), 137-146.

Kawabata, K., Mukai, R., Ishisaka, A. (2015) Quercetin and related polyphenols: new insights and implications for

their bioactivity and bioavailability. Food and Function, 6 (5), 1399-1417.

Lattimer, J.M., Haub, M.D. (2010) Effects of dietary fiber and its components on metabolic health. Nutrients, 2 (12), 1266-1289.

Lazarov, K., Werman, M.J. (1996) Hypocholesterolaemic effect of potato peels as a dietary fibre source. Medical Science Research, 24 (9), 581-582.

Leklem, J.E., Reynolds R.D. (1987) Clinical and physiological applications of vitamin B-6. New York: Alan R Liss Inc, 3-425.

Liu, R.H., (2013) Health-promoting components of fruits and vegetables in the diet. Advances in Nutrition, 4 (3), 384S-392S.

McGill, C.R., Kurilich, A.C., Davignon, J. (2013) The role of potatoes and potato components in cardiometabolic health: a review. Annals of Medicine, 45 (7), 467-473.

Mestdagh, F., Lachat, C., Baert, K., Moons, E., Kolsteren, P., Van Peteghem, C., De Meulenaer, B. (2007) 372 Importance of a canteen lunch on the dietary intake of acrylamide. Molecular Nutrition \& Food Research, 51 (5), $509-516$.

Murphy, M.M., Douglass, J.S., Birkett, A. (2008) Resistant starch intakes in the United States. Journal of the American Dietetic Association, 108 (1), 67-78.

Navarre, D. A., Payyavula, R. S., Shakya, R., Knowles, N. R., Pillai, S. S. (2013) Changes in potato phenylpropanoid metabolism during tuber development. Plant Physiology and Biochemistry, 65, 89-101.

Paturi, G., Nyanhanda, T., Butts, C.A., Herath, T.D., Monro, J.A., Ansell, J. (2012) Effects of potato fiber and potatoresistant starch on biomarkers of colonic health in rats fed diets containing red meat. Journal of Food Science, 77 (10), $\mathrm{H} 216-\mathrm{H} 223$.

Priestley, H. (2006) "How to think like consumers... and win!". In Potato developments in a changing Europe, Edited by: Haase, N. U. and Haverkort, A. J. 189-198. Wageningen Academic Pub. Chap. 20.

Shepherd, S.J., Gibson, P.R. (2013) Nutritional inadequacies of the gluten-free diet in both recently-diagnosed and long-term patients with coeliac disease. Journal of Human Nutrition and Dietetics, 26 (4), 349-58.

Seth, A., Mossavar-Rahmani, Y., Kamensky, V., Silver, B., Lakshminarayan, K., Prentice, R., Van Horn, L., WassertheilSmoller, S. (2014) Potassium Intake and Risk of Stroke in Women With Hypertension and Nonhypertension in the 
Women's Health Initiative. Stroke, 45 (10), 2874-2880.

Shewry, P. R. (2003) Tuber storage proteins. Annals of Botany, 91 (7), 755- 769.

Slavin, J.L. (2008) Position of the American dietetic association: Health implications of dietary fiber. Journal of the American Dietetic Association, 108 (10), 1716-1731.

Spelbrink, R. E., Lensing, H., Egmond, M. R., \& Giuseppin, M. L. (2015). Potato patatin generates short-chain fatty acids from milk fat that contribute to flavour development in cheese ripening. Applied Biochemistry and Biotechnology, $176(1), 231-243$.

Sun, Y., Su, Y., Zhu, W. (2016) Microbiome-metabolome responses in the cecum and Colon of pig to a high resistant starch diet. Frontiers in Microbiology, 7, 779.

Tareke, E., Rydberg, P., Karlsson, P., Eriksson, S., Törnqvist, M. (2002) Analysis of acrylamide, a 384 carcinogen formed in heated foodstuffs. Journal of Agricultural and Food Chemistry, 50 (17), 4998-5006.

USDA United States Department of Agriculture Release 16, NDB Number 11352, 04/01/2019.

Volpe, S.L. (2013) Magnesium in disease prevention and overall health. Advences in Nutrition, 4 (3), 378S-383S.

Watada, A. E. and Kunkel, R. (1955) The variation in reducing sugar content in different varieties of potatoes. American Journal of Potato Research, 32 (4) , 132-140.

Willcox, J.K., Ash, S.L., Catignani, G.L. (2004) Antioxidants and prevention of chronic disease. Critical Reviews in Food Science and Nutrition, 44 (4), 275-295.

Woolfe, J.A., Poats, S.V. (1987) The Potato in the Human Diet. New York: Cambridge University Press.

Zhu, F., Cai, Y-Z., Ke, J. and Corke, H. (2010) Compositions of phenolic compounds, amino acids and reducing sugars in commercial potato varieties and their effects on acrylamide formation. Journal of the Science of Food and Agriculture, 90 (13), 2254-2262.

Prispjelo/Received: 29.11.2019.

Prihvaćeno/Accepted: 9.12.2019.

Review paper

\section{Potato's Nutritional Value and its impact on human health}

\section{Abstract}

Since the world population is growing, the FAO (Food and Agriculture Organization of the United Nations) considers potato as an important food that could play a major role as a basic food for present and future generations. It has a great importance in human nutrition for many reasons: easy way of cultivation, high yields and consumption, acceptable price, simple and different ways of preparation. Since the potato is consumed in larger amounts, small differences in potato nutritional composition have major impact on population's health. The potato is a carbohydrate-rich food (starch), while protein content is low but has an excellent biological value of 90-100 (relative to the egg protein reference value of 100). Potato contains vitamin C and several B vitamins. Furthermore, potato represents a good source of potassium in an amount significantly higher in comparison with major food sources of potassium, such as broccoli, bananas and oranges. Many various phytonutrients in potato contribute to antioxidant activity. Phenolic acids such as chlorogenic and caffeic acid, flavonoids, carotenoids, and many other compounds belong to these important compounds that reduce free radicals effect and thus contribute to health. The skin provides substantial amount of dietary fibers. Besides nutrients, potato tubers also contain some undesirable substances, antinutrients, glycoalkaloids solanine and chaconine, but in healthy consumer potatoes they are found in quantities notably below the maximum levels. Therefore, this paper summarizes only the data on the nutritional properties of potato and their effect on human health.

Keywords: potato, nutritional ingredients, processing, phytochemicals, health 